An International Journal of Language, Literature and Gender Studies (LALIGENS)

Ethiopia

Vol. 3 (2), Serial No 8, May, 2014:66-88

ISSN: 2225-8604(Print) ISSN 2227-5460 (Online)

http://dx.doi.org/10.4314/laligens.v3i2.5

\title{
NOMINAL PLURALITY IN AGWAGUNE: A DESCRIPTIVE ANALYSIS
}

\author{
UGOT, MERCY, Ph.D. \\ Department of Language and Linguistic Science, \\ Cross River University of Technology \\ P.M.B 1123, Calabar. \\ Cross River State, Nigeria \\ E-mail: mercyugot@yahoo.com \\ Tel: +2348037102294
}

\begin{abstract}
This paper attempts to examine nominal plurality in the Agwagune Language of Cross River Sate, Nigeria. The Language belongs to the Niger-Congo phylum. In a descriptive analysis, focus is on the structure and functions of nominal plurality in Agwagune nominals. Data for this study was based on the lexicon preserved by the researcher in a previous study which was in turn collated by naturally occurring speech of the native speakers of Agwagune. Agwagune can be pluralized through a process of stem change, prefixation and through nominal modifiers, such as numerical adjectives, determiners and demonstratives. It has also been
\end{abstract}


discovered that nominal plurality in Agwagune through stemchange is human- specific only. Non-specific nominals are only overtly marked for plurality when they are accompanied by a modifying demonstrative.

Key words: Agwagune, modifiers, nominals, stem-change, vowel alternation

\section{Introduction}

This paper attempts to examine nominal plurality in Agwagune, a language of the Niger-Congo Phylum spoken in Cross River State, Nigeria. According to Crystal (2003) nominals are in some grammatical descriptions, a term used as a substitute for nouns. For example, a nominal group is also a noun phrase. In a more restricted sense, nominals refer to words which have some of the attributes of nouns but not all. For example, "the poor are many" where the head word of this phrase does not pluralize to become "the poors".

Number, on which plurality is based, is according to Crystal (2003) a grammatical category used for the analysis of word classes displaying such contrasts as singular, plural, dual, trial or apical (few) etc as in English boy vs. boys, he walks vs. they walk. The contrasts generally correspond to the number of real world entities referred to, but linguistic discussion has drawn attention to the problems involved in proposing any such straight forward one to one correlation. A noun for example, may 'look' singular but refer to a multiplicity of entities such as "the committee are agreed" (a collective noun) and nouns which "look" plural may refer to a single entity such as "billiards".

For the purpose of this work, we shall be looking at nominals that refer to nouns only.

\section{The Agwagune Language}

The Agwagune language is spoken in the political unit of Egip-Ipa clan in Biase Local Government Area (LGA) of Cross River State. The State is located in the South-South geo-political zone of Nigeria. The Agwagune language is the central language of the Nne group or 
Agwagune cluster of languages in Biase LGA, as there is mutual intelligibility among these languages. They include Agwagune, Erei: Adim, Abini, Etońo II, Abayongo and Etono central speakers.

The Agwagune language has been classified by Faraclas (1989), Williamson and Blench (2002), Essien (2003) as belonging to the Upper Cross group which in turn is a sub-group of the Delta Cross, which, together with Bendi, constitute the Cross River group, a significant sub-classification of the Niger-Congo Phylum.

\section{Literature Review}

\section{a) Plural Typologies in Language}

There are different typologies of plurality in language. Dryer (2011) insists that there are basically two ways in which languages indicate plurality. The first (and most common) involves changing the morphological form of the noun as in English dog, dogs. The second involves indicating plurality by means of a morpheme that occurs somewhere else in the noun phrase illustrated by the plural word as in the example in (1a) from Hawaiian where the word mau has the same function as the plural suffix in English but is a separate word modifying the noun.

$1 \mathrm{a}$.

$$
\begin{aligned}
& \text { élua a' u mau ia } \\
& \text { two my Pl fish } \\
& \text { 'my two fishes' }
\end{aligned}
$$

Other forms include indicating plurality morphologically on the noun. The first of these is plural prefixes as illustrated in (2a) to (2d) from Degema, a language of the Niger-Congo Phylum spoken in the NigerDelta of Nigeria, where two prefixes are listed for a given modem in

\begin{tabular}{|c|c|c|c|}
\hline 2 & oßí & 'ancestor' & pl. eßí \\
\hline & ómómósi & 'brother' & ímómósi \\
\hline$C$ & óm & 'child' & imó \\
\hline
\end{tabular}
the plural, the first attaches to the modem when it qualifies nouns denoting non-human entities (Kari 2003:240). 


d odim 'corpse Idim
and

3
a áikí
'cooking pot'
íikí
b ukpúró
'feather'
òkpúiró

Degema nominals are therefore formed through a change in the prefix or initial vowel syllable of the word from $/ \mathrm{s} /$ to $/ \mathrm{i} /, / \mathrm{u} /$ to $/ \mathrm{a} / \mathrm{,} / \mathrm{u} /$ to $/ \mathrm{o} /$. There is plurality marked in both human and non-human specific nominals.

Ugot (2008:201) observes a similar change for plurality in some Biase languages spoken in Cross River State to include Ukpet-Ehom cluster as in.
4

$\begin{array}{ll}\text { a } & \text { aga } \\ \mathrm{b} & \text { egbei } \\ \mathrm{c} & \text { ego }\end{array}$
'stone'
'day'
'house'
iga
igbei
ige

where pluralization occurs when the back vowels alternate with front and central vowels to yield plurals. The rule applies to both human and non-human specific objects, as in (5a) to (5c)

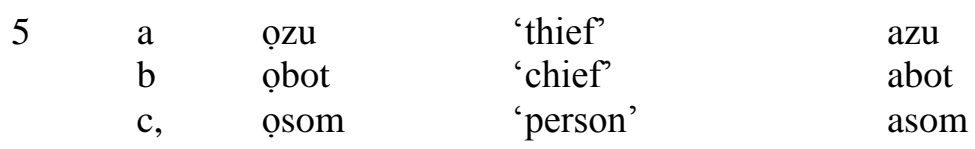

In Gandu, a language spoken in Uganda, again we have inflectional markings as in, (6a) to (6d).

From this we can see that there is an inflectional prefix omи - used with singular nouns and a different inflectional prefix $a b a$ - used with the plural of those nouns.

$\begin{array}{lll}6 & \mathrm{a} & \text { omusawo } \\ & \mathrm{b} & \text { omukazi } \\ \mathrm{c} & \text { omuwala } \\ \mathrm{d} & \text { omusika }\end{array}$

$\begin{array}{ll}\text { 'doctor' } & \text { abasawo } \\ \text { 'woman' } & \text { abakazi } \\ \text { 'girl' } & \text { abawala } \\ \text { 'heir' } & \text { abasika }\end{array}$

Yule 1985: 65 
If a language expresses plurality by reduplicating only part of the stem, then the language is classified here as prefixing or suffixing depending on whether it is the initial or final segment of the stem that is reduplicated. Dryer (2011) citing Campbell (1985:52) highlights this through

7

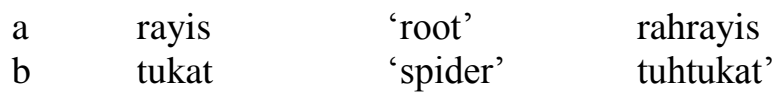

The following data from llocano, a language of the Philippines will serve to illustrate a partial reduplication for marking plurality.

8.

$\begin{array}{ll}\text { a } & \text { úlo } \\ \text { b } & \text { dálan } \\ \text { c } & \text { bíag } \\ \text { d } & \text { múla }\end{array}$

'head'
'road'
'life'
'plant'

ulúlo

daldálan

bibíag

mulmúla

Yule 1985: 65.

In Leggbo, an Upper-Cross language in Cross River State, Nigeria, Udoh (2004:14) cites an example of total reduplication being used to mark the grammatical category of plurality. Such grammatical reduplication is written spaced out as in (9a).

a Lettol ggwénè ggwénè

Head white

'White heads'

Where the adjective modifying the nominal takes on the grammatical category of plurality or is used to mark plurality.

Another way of forming plurality is by tone. This is the primary means for a lot of languages in Africa of the Niger-Congo phylum such as, Ngiti spoken in Democratic Republic of Congo (Dryer 2011)

$\begin{array}{lllll}\text { 10. } & \mathrm{a} & \text { kamà } & \text { 'chief' } & \text { kámá } \\ \mathrm{b} & \text { màiàyìkà } & \text { 'angel' } & \text { màlàyíká } \\ \mathrm{c} & \text { màlimò } & \text { 'teacher' } & \text { màlímó }\end{array}$


In Ibibio, a Lower Cross language of the Benue-Congo family (Williamson 1989) spoken in Akwa Ibom state, Nigeria, most nouns do not have lexicalized plural markers. Urua (2000:90) observes that a separate morpheme is used to mark plurality on nouns.

The plural marker is the morpheme m̀mè. Like noun modifiers, m̀mè occurs preceding the noun and since most Ibibio nouns begin with a vowel prefix, then the condition for vowel deletion is created given the fact that the plural marker ends with a vowel.

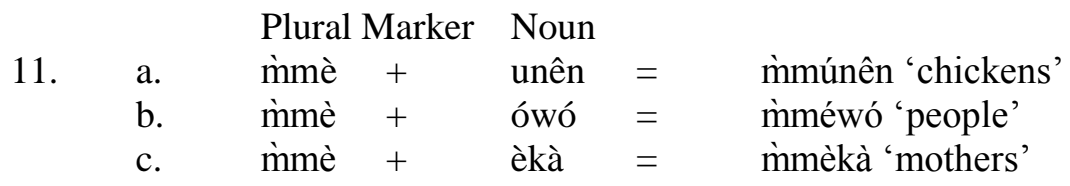

There are also languages that form their plurals by employing two or more of the methods already described with little basis for saying which of them is considered the method.

Ugot (2008:202) cites the Ubaghara language (spoken in Biase, Cross River State, Nigeria) as having a separate morpheme to form plurals in non-human specific objects only. Plurality is indicated by the addition of a qualifying adjective - $\underline{\text { eme }}$

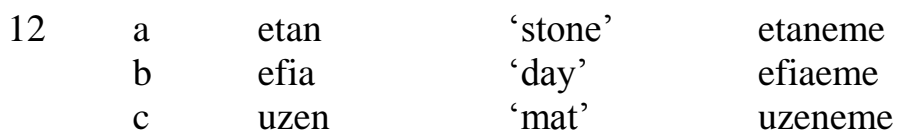

The rule governed vowel alternation is applied to human-specific nouns.

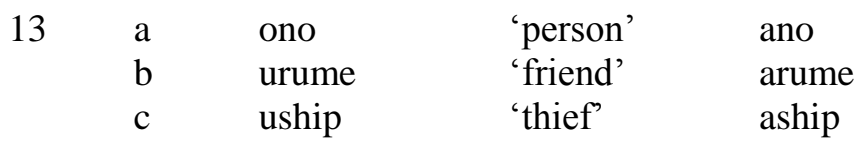

In some human-specific nouns another pluralization technique involves the addition of the nasal $/ \mathrm{m} /$ initially.

14 a egbu 'ghost' megbu 
b. inyon 'witch' meanyon

Ugot (2008:203) also observes that Erei (of the Nne group or Agwagune cluster) does not appear to have a hard and fast rule of plurality in non-human specific nouns, as demonstrated below:

15
a ushi
'bag'
ushi
b. okpokolo
'table'
okpokolo

but
c. uko
'book'
iko
d. iyọ
'hen'
uyo

where there is an interchange of prefixes indicating singularity and plurality. Other ways of forming plurality include changes within the noun stem as the primary means of forming plurals in the languages. This involves changes in the vowels within the noun stem, a means used for a number of nouns in English with irregular plurals such as 16
a man,
men
b. goose,
geese

This is also seen in the illustration in Maricopa (Dryer citing Gordon 1989: 29).

$\begin{array}{rlll}17 \text { a } & \text { humar } & \text { 'child' } & \text { humaar } \\ \text { b. } & \text { hat } & \text { 'dog' } & \text { haat } \\ \text { c. } & \text { nchen } & \text { 'older sibling } & \text { nchun } \\ \text { c. } & \text { mhay } & \text { 'boy' } & \text { mhaa }\end{array}$

Akmajia, Demers, Farmer \& Harmish (2008:18) observe an important characteristic of Swahili, which is that it possesses a rich set of prefix pairs that are used with different classes of nouns. One prefix pair is $k i$ - and $v i$-, used for singular and plural nouns respectively. Thus we have

18 a kipilefti 'a traffic circle'

vipilefti 'traffic circles' 
There are plural words and plural clitics. Plural words as seen in (1a) are words whose meaning is like that of plural affixes but they are separate words. Plural clitics on the other hand are probably best seen by as a type of plural word, whose position is defined syntactically in that they have a specified position within the noun phrase, but which attach phonologically to whatever word happens to occur adjacent to that position within a particular noun phrase (Dryer 2011). For example in Cayuvara (Spoken in Bolivia) the plural clitic me-attaches to whatever is the first word in the NP as in

19

$$
\begin{array}{ll}
\text { me - riŝ } & \text { rah } \\
\text { P l- new } & \text { paddle } \\
\text { 'new paddles' } &
\end{array}
$$

The plural clitic may also follow the modifier of the noun, except for numerals which it precedes, and attaches to an adjective as in Sinaugoro spoken in Papua New Guinea (Kolia 1975:124).

21 a belema bara = ná tautatoitoi

$\begin{array}{lcl}\text { Python big } & \text { pl } & \text { six } \\ \text { 'Six } & \text { big } & \text { pythons' }\end{array}$

Again there are languages that apparently lack a morphological plural with no evidence of plural words or clitics. Although such languages may simply not indicate plurality at all the plurality of nominal referents is coded on the verb if the nominal is an argument of the verb.

Plurality in many languages is limited or restricted to human nouns or a sub-set of a human noun.

\section{b) The Occurrence of Plural Markers}

Having seen the different ways plural markers can have formal manifestation let us look at the occurrence of plural markers which varies along at least two dimensions of animacy and obligatoriness (Haspelmath 2011). 
In the animacy dimension, the most important contrast is between animate (especially human) and inanimate nouns. In the obligatoriness, distinction is made between non-occurrence, optional occurrence and obligatory occurrence. According to Haspelmath (2011) occurrence of nominal plurality can therefore be:

1) No nominal plurals

2) Plural only in human nouns (optional)

3) Plural only in human nouns (obligatory).

Although there may be no overt plural marking in inanimate (nonhuman) nominals, there is plural meaning. A non number marked form of the noun is used both for a single referent and for a group of referents.

Haspelmath (2011) citing Kilan-Hatz (1995:215) says in Ubangi (Niger-Congo Phylum) spoken in Cameroun where all nominal plurals are optional the noun form $g b a$ can be translated as 'village' or 'villages'. Speakers can be explicit and use the plural form gba-o 'villages' but they do not have to.

In principle, obligatory occurrence of plural marking means that whenever plural reference is intended, the plural must be used. However, languages with otherwise obligatory plural marking very often allow it to be absent when the noun co-occurs with numerals and other quantity words. Another special circumstance under which plural marking is often lacking is non-referential or generic use.

Haspelmath (2011) explains the role of animacy in plural marking to be the fact that the distinction between one and more than one is more salient for animates. According to Napoli (1996) many languages have a dual number. Attic Greek, for example, makes a morphological distinction among singular, dual and plural (where plural means three or more) on nouns.

Hudson (2001:49) points out that in a language called Yucatec Maya spoken in Mexico, the marking of plural is optional in Maya so pèek 
for example means either 'dog' or 'dogs'. It is possible to distinguish a group from a single individual by means of an optional elementó 'ob', so peek-ó 'ob' means dogs not dog, but this marking is optional. Through grammaticalization this preference in language use can lead to obligatoriness in language structure. After noting that in Yoruba the plural word àwon is optional, Rowland (1969:41) goes on to explain that the plural marker is used if the referent is thought of as a group of individuals, where as no marker is used if it is thought of collectively as in

21.

$\begin{array}{cll}\begin{array}{cl}\text { àwon } \\ \text { PL }\end{array} & \text { ìwé } & \text { mi } \\ \text { 'My various } & \text { books } & \text { my } \\ & \text { Or } & \end{array}$

'My collection of books vs 'my book'

\section{Theoretical Framework and Methodology}

This work is based on two theories. The first of these is the Sapirwhorf hypothesis which focuses on the relationship between language and thought, which asserts that language, determines the way people perceive and organize their worlds. This hypothesis was initially known as linguistic relativity, (Crystal, 2003).

According to Hudson (2001) different languages do not simply provide different ways of expressing the same ideas, but they are also different in the more fundamental sense, in that the ideas can be expressed differently from language to language. This, Hudson refers to as semantic relativity. There are no limits on variation apart from whatever limits formation. All concepts that serve as word-meaning in different languages are simply different ways of combining a limited range of rather basic 'components'. In English for example, the verb eat is translated into German in two different ways according to whether the eater is a human (essen) or an animal (fresson) Both German verbs according to Hudson (2001) have a more specific 
meaning than eat. It is apparent that the immediate components of culture-specific concepts must themselves continue to be so.

The strong form of the Sapir-Whorf hypothesis is generally labeled as linguistic determinism. This holds that people from different cultures think differently because of differences in their languages. Most people accept the claim of linguistic relativity that language influences perceptions, thought, and at least potentially, behaviour. The categories provided by a language may make it easier to draw certain conceptual distinctions (Lucy 1992).

Again, we shall ascribe to the unitary base hypothesis. It has been claimed that word-formation processes select the domain over which they operate and that, that domain must be definable as a single morpho-syntactic or semantic type. This claim according to Napoli (1996) is known as the unitary base hypothesis (UBH). It follows from the UBH that every affix we look at should restrict the set of stems to which it can attach in a way that should be statable with a single morpho-syntactic or semantic statement. It is, in fact, quite common to find affixes that can attach only to adjectives or only to verbs or only to nouns.

Data for this work was based on the lexicon presented by Ugot (2008), which in turn was collated by naturally occurring speech of the native speakers of Agwagune.

\section{Agwagune Nominals and Plurality}

The semantic correlation of the category of number is usually distinguished between singularity and plurality. In Agwagune specific word forms associated with objects are not assigned numbers. In other words, plurality in Agwagune is human specific. Agwagune nonhuman specific nouns are marked by zero morphs in their plural forms, they are unmarked for number as in (22). Ugot (2008) insists that the basic noun in Agwagune is made up of a prefix and a stem. There are very few nouns without prefixes as roughly only 9 out of 222 listed nouns in Ugot's (2008) Ibadan 400 word lists were without 
a vowel prefix. The prefix may have been fused with the stem at a time in the etymology of the language.

22

$\begin{array}{ll} & \text { Singular } \\ \text { a) é-tán } \\ \text { b) é-jé } \\ \text { c) é-kpộộdák } \\ \text { d) dọñ } \\ \text { e) ẹ-zám } \\ \text { f) wẹẹ́doñ } \\ \text { g) í-zík } \\ \text { h) } \quad \text { í-dút } \\ \text { i) ì-sáni } \\ \text { j) i-gwùgùn } \\ \text { k) ò-kpó }\end{array}$

$\begin{array}{ll}\text { Plural } & \text { 'Gloss } \\ \text { ẹ-tán } & \text { 'stone/rock' } \\ \text { ẹ-jé } & \text { 'day' } \\ \text { é-kpộộdák } & \text { 'shoe' } \\ \text { dọñ } & \text { 'house' } \\ \text { ẹ-zám } & \text { 'farm' } \\ \text { wẹ́ẹ́doñ } & \text { 'room' } \\ \text { 1-zík } & \text { 'rope' } \\ \text { 1-dút } & \text { 'calabash' } \\ \text { ì-sáni } & \text { 'mat' } \\ \text { i-gwùgùn } & \text { 'star' } \\ \text { ò-kpó } & \text { 'hat/cap' }\end{array}$

In Agwagune, it is in the human-specific noun that only plural is obligatory. There are also no overt plural marking for nouns denoting non-discrete masses such as sand, salt, water, milk which often lack plurals even in languages that otherwise mark the plural of inanimates such as the English language.

23).

\section{Singular}

a) úbbú

b) únúk

c) màn

d) mànibi
Plural

úbbú

únúk

màn

mànibi
Gloss

'sand'

'salt'

'water'

'milk'

\section{Prefix and Stem Change - Vowel Alternation}

The system of pluralization in Agwagune is mostly rule-governed where back vowels alternate with front and central vowels to yield plurals. Such plurality is marked overtly in human specific nouns only, (Ugot 2002). The change to plurality often occurs in a change of the initial morpheme (prefix) as in (24a) to (24i). 
24.

\section{Singular}

a) ò̀-sọ̀m

b) ú-ship

c) ú-gbúgbà

d) ú-bbú

e) 1́-nùn

f) o-zèm

g) ọ́-bọ́bộhọ́

h) ú-ròmò

i) ú-ségót plural

à-sòm

é-ship

1-gbúgbà

1́-bbú

1́-nùn

i-zèm

á-bọ́bộhọ́

é-ròmò

á-sẹgọ́t
Gloss

'person'

'thief'

'female adolescent'

'ghost'

'chief'

'witch'

'native doctor'

'friend'

'hunter'

Words that begin with back vowels in the singular are usually displaced by either front or central vowels in the plural. The vocalic pattern is as follows:

25.
a)
$\mathrm{O} \longrightarrow \mathrm{a}$
b)
c)
$\mathrm{u} \longrightarrow \mathrm{e}$
d)
$\mathrm{O} \longrightarrow \mathrm{i}$
$\mathrm{u} \longrightarrow \mathrm{a}$
e)
$\mathrm{u} \longrightarrow \mathrm{i}$

In some cases both the first and second syllables are affected by this vocalic alternational pattern, as in (26a) to (26c). Again, this is for human-specific nouns only.

26.

Singular
a)
ọnọoọgèn
b) ónúròm
c) ọnẹégwá

\section{Plural}

anéègèn

ánéròm

ánẹeẹ́bá
Gloss

'stranger'

'man'

'woman'

\section{Stem Change - Consonant and Vowel Alternation}

Another rule-governed pluralization technique in Agwagune is through modification - replacing the bilabial approximant $/ \mathrm{w} /$ and the digraph /gw/ by a bilabial plosive /b/. Thus we have in (26c), (27a) 
to $(27 \mathrm{e})$ the consonant alternation occurring at the same time as the vowel alternation.

27

\section{Singular}

a) wóónúròm

b) wúwòrí

c) gwá-ẹ

d) gwañ

e) wáákà
Plural

bánéròm

bébòrí

bá-è̀

bañ

báákà
Gloss

'son'

'child'

'wife'

'child'

'sibling'

We have observed that consonant alternation is not limited to a particular environment. Plurality also embodies the changing of back vowels to central or front vowels in the plural. Let us examine how plurality is marked when the nominal has a modifier.

\section{Nominal Modifiers}

Nominal modifiers occur in the vicinity of nouns or pronouns, and have the ability to specify or limit the reference of the nouns or pronouns. Nominal modifiers belong to a closed class, (Ndimele 1999). Emenanjo (1978:70) defines nominal modifiers as "A cover term for those 'qualifying' words which, even though they occur in the NP, can never be used alone in a minimal NP".

Nominal modifiers include determiners, demonstratives, numbers and adjectives. These modifiers are used to mark plurality and number in Agwagune nominals. Modification is a term used in syntax to refer to the structural dependent of one grammatical unit upon another but with different restrictions in the scope of the term being introduced by different approaches, (Crystal 2003)

Napoli (1996) asserts that when an A modifies a noun, then the form we find is an adjective and when an A modifies anything other than a noun, the form we find is an adverb. For the purpose of this paper, we shall stick to A modifying the noun and look at the modifying adjective. 


\section{a) Numerical Adjectives}

Ndimele (1993) points out that an attributive adjective occurs in the vicinity of the noun that it modifies. Both the noun and the adjectives must occur in the same noun phrase.

Numerals as nominal modifiers indicate a specific number of an entity and follow the head noun like determiners. Pluralization occurs in numerical adjectives in Agwagune only when the adjective is qualifying a human - specific noun. If the noun is non-human, the adjective remains in the singular form as the noun as in (28a) to (28d). Although the plural is clearly understood it is not overtly marked.

$\begin{array}{llll}\text { 28a) } \begin{array}{lll}\text { ẹià } \\ \text { dog }\end{array} & \begin{array}{l}\text { ínâ } \\ \text { four }\end{array} & \text { 'four dogs' } \\ \text { b) } \begin{array}{l}\text { okpókóró } \\ \text { table }\end{array} & \begin{array}{l}\text { íâ } \\ \text { two }\end{array} & \text { 'two tables' } \\ \text { c) } \begin{array}{l}\text { nwẹ̀t } \\ \text { book }\end{array} & \begin{array}{l}\text { ívàn? } \\ \text { how many? }\end{array} & \text { 'how many books? } \\ \text { d) mgbàñmgbàn } & \text { ítàt } & \text { 'three plates' }\end{array}$

From (29a) to (29d) however, we have human specific nouns. The vowel prefix in the adjectives change to that of plurality

$\begin{array}{rlll}\text { 29a) ánéròm } & \text { á-nâ } & \text { 'four men' } \\ \text { men } & \text { four } & \\ \text { b) àsọ́m } & \text { á-fâ } & \text { two persons' } \\ & \text { persons } & \text { two } & \\ \text { c) ánẹẹ̀bá } & \text { á-vàn } & \text { 'how many women' } \\ & \text { women } & \text { how many? } & \\ \text { d) } & \text { éshìp } & \text { á-tàt } & \text { 'three thieves' } \\ & \text { thieves } & \text { three } & \end{array}$




\section{b) Determiners}

All indefinite or unspecified NPs occur without a determiner. When it is necessary to definitize, one way of doing this is to use a determiner (Essien 1990). Determiners according to Crystal (2003) are used in some models of grammatical description referring to a class of items whose main role is to co- occur with the nouns to express a wide range of semantic contrasts such as quantity or number. The articles of a language are the main sub-sets of determiners e.g. their in English. Other determiners which can have a determiner function in English include each/every; this /that / some /any.

Some linguists extend the application of this term to include other types of words within a noun phrase (NP) such as adjectives, predeterminers and modifiers in other parts of the sentence. In Generational Grammar (GG) theories, the determiner is regarded as the head in combination with a noun to produce a determiner phrase (Det P).

Napoli (1996) says there is some controversy in deciding what words like all, some, few are, and numerals like one, ten, a thousand. Some argue that they are lexical categories while others argue that they are functional categories, more like determiners. Essentially words with minimal sense of their own which function largely to give information about the words they introduce - as determiners like the do - are function words. Determiners and certain propositions like of and to but not prepositions that indicate spatial or temporal relationships such as under or after along with a handful of other kinds of words are called function words (Napoli (1996:204).

In Agwagune the determiners can be used to indicate number and plurality in nominals and are also human and non- human specific in application. The determiners in Agwagune can also be used as demonstratives.

$\begin{array}{ll}\text { 30a) ộnẹẹgwá nwè̀ } & \text { 'the woman' } \\ \text { woman } & \text { the }\end{array}$




$\begin{array}{lll}\text { b) ánèèbá } & \text { nwèbe } & \text { 'the women' } \\ \text { themen } & \text { nwè } & \text { 'the man' } \\ \text { 31a) ónúròm } & \text { the } & \\ \text { b) ánéròm } & \begin{array}{l}\text { nwèbe } \\ \text { men }\end{array} & \text { the }\end{array}$

For non-human nominals the determiner behaves the same but the nominal does not change in plurality.

$\begin{array}{rll}\text { 32a) ẹbìà } & \text { nwẹ } & \text { 'the dog', } \\ \text { b) ẹbìà } & \text { nwèbe } & \text { 'the dogs' }\end{array}$

\section{c) Demonstratives}

Demonstratives also help in Agwagune to mark plurality in nominals. Lyons (1995) remarks that as primary deixis, the English demonstratives can be analyzed in terms of the notion of Spatio temporal proximity to the deictic centre. 'This' and 'here' refer to entities and places that contain the speaker or point to a period of time that are located in the period of time that contains the moment of utterance. Lyons distinguishes between physical and emotional proximity or remoteness. Crystal (2003) defines a demonstrative as a class of items whose function is to point to an entity in the situation or elsewhere in the sentence. The items: 'this' and 'that' for example have their reference fixed by gestures, speakers, knowledge or other means. The demonstratives 'this' and 'that' used as deictics can be understood as instructing or inviting the addressee to direct his attention to a particular region of the environment in order to find what is being referred to.

Demonstratives according to Akmajian et al (2008) belong to closed class words that belong to grammatical or function classes which in any language tend to include a small number of fixed elements. Function words in English include conjunctions (and, or) articles (the, 
a) demonstratives (this, that) quantifiers (all, most, some, few) and prepositions (to, from, at, with).

Demonstratives involve a supplementary gesture (demonstration) or special setting in order to determine reference. Typical examples include
a) this, these
b) that, those
c) he, she, it
d) you

Using demonstratives successfully to refer involves more than just the aspects of the context of utterance required by indexicals (speaker, place, time etc). Ugot (2007: 14) opines that Agwagune has a fourway opposition with its third and fourth variants used mostly for emphasis. In this work, we are interested in seeing how demonstratives mark plurality in nominals.

In $(34 a)$ to $(34 d)$ there is no overt change in the non-human nominal but plurality is reflected in the accompanying demonstrative.

34

$\begin{array}{llll}\text { a) nwẹ̀t } & \begin{array}{l}\text { jè }(\mathrm{sg}) \\ \text { this }\end{array} & \text { 'this book' } \\ \text { book } & \text { nwẹ̀t } & \begin{array}{l}\text { bè }(\mathrm{plu}) \\ \text { these }\end{array} & \text { 'these books' } \\ \text { book } & \text { nwè }(\mathrm{sg}) & \text { 'that book' } \\ \text { c) } & \text { that } & & \\ \text { book } & \text { nwèt } & \text { nwèbè (plu) } & \text { 'those books' } \\ \text { d) book } & \text { those } & \end{array}$

In (35a) to (35d) singularity and plurality are reflected in both the human-specific nominals and their demonstratives. 


$\begin{array}{lll}\text { b) ánèẹ́bá } & \begin{array}{l}\text { bè }(\mathrm{pL}) \\ \text { these }\end{array} & \begin{array}{l}\text { 'these } \\ \text { women }\end{array} \\ \text { c) ọnèẹ̀gwá } & \begin{array}{l}\text { nwẹ }(\mathrm{sg}) \\ \text { that }\end{array} & \text { 'that woman' } \\ \text { d) ánèẹ̀bá } & \begin{array}{l}\text { nwèbè }(\mathrm{pl}) \\ \text { those }\end{array} & \begin{array}{l}\text { 'those } \\ \text { women }\end{array}\end{array}$

\section{Conclusion}

This work has explored the structure and formation of nominal plurality in Agwagune. Nominals in Agwagune can be pluralized through a process of stem change, prefixation and nominal modifiers which can also identify plurality in the nominals. These have been seen to be done through numerical adjectives, determiners, and demonstratives. It has also been observed that nominal plurality in Agwagune through stem change is human - specific only while others remain unchanged. However, non-human specific nominals are overtly marked in plurality when they are accompanied by modifying demonstratives which are marked for plurality.

It is hoped that this study will contribute to the morphology and grammar of the Agwagune language within the growing need for proper documentation of minority languages in Nigeria.

\section{References}

Akmajian, A., Demers, R. A., Farmer, A.R. \& Harnish, R. M. (2008). Linguistics: An introduction to language and communication. New Delhi: Prentice Hall of India.

Crystal, D. (2003). A dictionary of linguistics and phonetics. Oxford: Blackwell publishing

Dryer, M. S. (2011). Coding of nominal plurality. In Dryer, M. S. \& Hasplemath, M. (eds). The world atlas of language structures. Online. Munich; max Planck Digital library. Chapter 33. 
Available online at http://wals. info/chapter33. Accessed on 2013-8-24.

Emenanjo, E. N. (1978). Elements of Modern Igbo grammar. Ibadan: Oxford, University Press.

Essien, O. E. (1990). A grammar of the Ibibio language. Ibadan: University Press Ltd.

Essien, O. E. (2003) Linguistic variations among the small minorities of Akwa Ibom and Cross River States. In O.E .Essien \& M.Okon (eds). Topical issues in sociolinguistics: the Nigerian perspective. Pp 387-401. Aba: National Institute for Nigerian Language.

Faraclas, N. G. (1989). The Cross River Languages. In J. Bendor Samuel (ed). The Niger - Congo languages. Pp. 177-397. Lanham: University press of America.

Haspelmath, M. (2011). Occurrence of nominal plurality. In Dryer, M. S. Haspelmath M. (eds). The world atlas of language structures Online. Munich: max Planck digital library chapter 34. Available Online at http://wals. Info/chapter /34. Accessed on $2013-8-24$.

Holmes, J. (2008). An introduction to sociolinguistics. Essex: Pearson. Education Ltd.

Hudson, R. A. (2001). Sociolinguistics. Cambridge: C.U.P

Kari, E. E. (2003). Clitics in Degema: a meeting point of phonology, morphology, and syntax Tokyo: Research institute for languages and cultures of Asia and Africa ILCAA.

Lucy, J. A. (1992). Grammatical categories and cognition: A case study of linguistic relativity hypothesis. Cambridge: Cambridge University press.

Lyons, J. (1995). Linguistic semantics: An introduction. Cambridge: CUP. 
Napoli, D. J. (1996). Linguistics. Oxford: Oxford University Press.

Singleton, D. (2000). Language and the lexicon: An introduction. London: Arnold (Hodder Headline Group).

Udoh, I.I. (2003). The languages of Cross River State. In 1. 1. Udoh (ed). The languages of the South-South zone of Nigeria. A Geo-political Profile Pp 51-69. Lagos: concept publications.

Udoh, I. I. (2004) Leggbo Lexicon. Port Harcourt: Emhai publications.

Ugot, M. I. (2002). Affixation in Agwagune. Global Journal of humanities $2: 1 \& 2.28-31$.

Ugot, M. I. \& Offiong A.O. (2007) Deictic Categories in Agwagune. International Journal of linguistics and communication. 1:2 $14-24$.

Ugot, M. I. (2008). Aspects of Agwagune morphology. An unpublished Doctoral thesis. Faculty of arts. University of Calabar.

Urua, E.E. (2000). Ibibio phonetics and phonology. Cape Town: Centre for Advanced Studies of African Society.

Williamson, K \& Blench, R. (2002). Niger-Congo. In B. Heine \& D. Nurse (eds.) African Languages: An Introduction. Pp 11-42 Cambridge: Cambridge University Press.

Yule, G. (1985). The Study of Language. Cambridge: Cambridge University Press. 
Table 1 Percentage of Response on Variable 1 - 12

\begin{tabular}{|c|c|c|c|c|}
\hline $\mathbf{S} / \mathbf{N}$ & VARIABLES & YES & NO & TOTAL \\
\hline 1. & $\begin{array}{l}\text { Is the Biase language spoken in this } \\
\text { community your mother tongue? }\end{array}$ & & & \\
\hline 2. & Do you teach primary $1-32 ?$ & & & \\
\hline 3. & Do you teach Primary $4-6 ?$ & & & \\
\hline 4. & Is the Biase language taught as a subject & & & \\
\hline 5. & $\begin{array}{l}\text { Do you use the Biase language as a medium } \\
\text { of instruction? (i.e. to teach) }\end{array}$ & & & \\
\hline 6. & $\begin{array}{l}\text { Area you aware that the National Policy on } \\
\text { Education states that the mother tongue } \\
\text { (NT) or the Language the Immediate } \\
\text { Environment (LIE) should be used as the } \\
\text { medium of instruction in primaries } 1-3 ?\end{array}$ & & & \\
\hline 7. & Do you as a teacher implement this policy & & & \\
\hline 8. & $\begin{array}{l}\text { Does the LGA Government encourage the } \\
\text { implementation of this policy? }\end{array}$ & & & \\
\hline 9. & $\begin{array}{l}\text { Do the majority of teachers teaching } \\
\text { primary } 1-3 \text { speak the Biase language of } \\
\text { this community? }\end{array}$ & & & \\
\hline 10. & $\begin{array}{l}\text { Do you think it is advisable to use the Biase } \\
\text { language to teach primary } 1-3 \text { ? }\end{array}$ & & & \\
\hline 11. & $\begin{array}{l}\text { Do you think the use of the Biase Language } \\
\text { millipede performance in other subject at } \\
\text { the higher classes? }\end{array}$ & & & \\
\hline 12. & $\begin{array}{l}\text { Are all your pupils natives of this } \\
\text { community. }\end{array}$ & & & \\
\hline
\end{tabular}




\section{QUESTIONNAIRES}

\section{Section A}

1. Educational Qualification

2. Class taught:

3. Local Government Area of Origin:

\section{Section B}

1. Is the Biase language spoken in this community your mother tongue

2. Do you teach primary 1-3? Yes
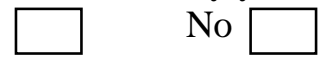

3. Do you teach primary 4-6? Yes

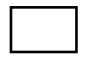

4. Is the Biase language taught as a subject.

No
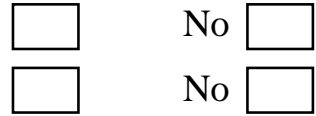

No $\square$

Yes
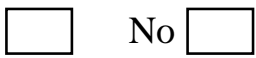

5. Do you use the Biase language as a medium of instruction? (i.e. to teach) Yes

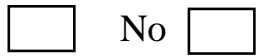

6. Are you aware that the National Policy on Education state that the Mother Tongue (MT) or the language or the language of the immediate environment (LIE) should be used as a medium of instruction in primary 1-3?

Yes

7. Do you as a teacher implement this policy? Yes

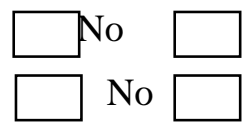

8. Does the LGA Government encourage the implementation of this policy?

Yes

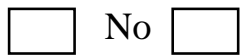

9. Do the majority of teachers teaching primary 1-3 speak the Biase language of this community?

Yes

No

10. Do you think it is advisable to use the Biase language to teach primary $1-3$ ?

Yes

No $\square$

11. Do you think the use of the Biase language will impede performance in other subjects at the higher classes?

Yes

No

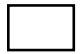

12. Are all your pupils natives of this community? Yes

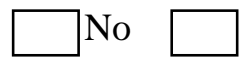

